\title{
Crassostrea virginica dredge efficiency in Texas estuaries
}

\author{
Jennifer Beseres Pollack (iD) and Terence A. Palmer (D) \\ Harte Research Institute for Gulf of Mexico Studies, Texas A\&M University - Corpus Christi, 6300 Ocean Drive, Unit 5869, \\ Corpus Christi, TX78412-5869, USA. \\ ${ }^{*}$ Corresponding author. Email: jennifer.pollack@tamucc.edu
}

(Received 22 October 2019; Accepted 22 November 2019)

\begin{abstract}
Quantifying and comparing stocks of oysters (Crassostrea virginica) within and among estuaries across the Gulf of Mexico is difficult because the sampling equipment used is either inconsistent among studies, or inefficient. In Texas, USA, stock assessments of oyster populations are made using an oyster dredge, which is an inefficient sampling tool. We compared sampling densities estimated by oyster dredges with more accurate estimates taken by diver-quadrat samples to determine a dredge efficiency rate. Our calculated efficiency rate ( 0.125 ) was negatively affected by the number of dead oysters, and the number and volume of total oysters in an area, but not affected by sediment grain size, water quality, and other oyster metrics. The dredge efficiency rate calculated in this study can be applied to past and future dredge-collected oyster quantity data to provide more realistic estimates of oyster densities and allow more accurate stock assessments and comparisons among studies and regions.
\end{abstract}

Keywords: Eastern oyster; Gulf of Mexico; gear efficiency; stock assessment

\section{Introduction}

An ongoing challenge to managing Crassostrea virginica oyster populations is the lack of standardized metrics for quantifying and comparing stock abundance within and among estuaries, states, and across the Gulf of Mexico. In Texas, stock assessments of subtidal oyster populations are conducted using an oyster dredge, which cannot provide oyster density or shell volume as a quantitative, comparable metric (e.g. per unit area). It is recognized that oyster dredges are inefficient samplers; they do not collect everything in their path and can vary widely across replicate samples (Chai et al., 1992). Dredge results can also be affected by towing speed, frequency of dredging, bottom characteristics, and length of towline (Meyer et al., 1981; McLoughlin et al., 1991; Powell et al., 2002). Resulting data may underestimate oyster densities (Chai et al., 1992) and limit the ability to estimate stock abundance and assess populations across states and/or regions.

\section{Objective}

The objective of this study is to determine a gear efficiency ratio for oyster dredging in shallow, subtidal estuaries that occur in the northern Gulf of Mexico. The purpose of determining this ratio is to allow the conversion of dredge-derived oyster data, such as that collected since 1984 by the Texas Parks and Wildlife Department fisheries-independent monitoring program (Martinez-Andrade 2018), to

\footnotetext{
(C) The Author(s) 2020. This is an Open Access article, distributed under the terms of the Creative Commons Attribution licence (http:// creativecommons.org/licenses/by/4.0/), which permits unrestricted re-use, distribution, and reproduction in any medium, provided the original work is properly cited.
} 


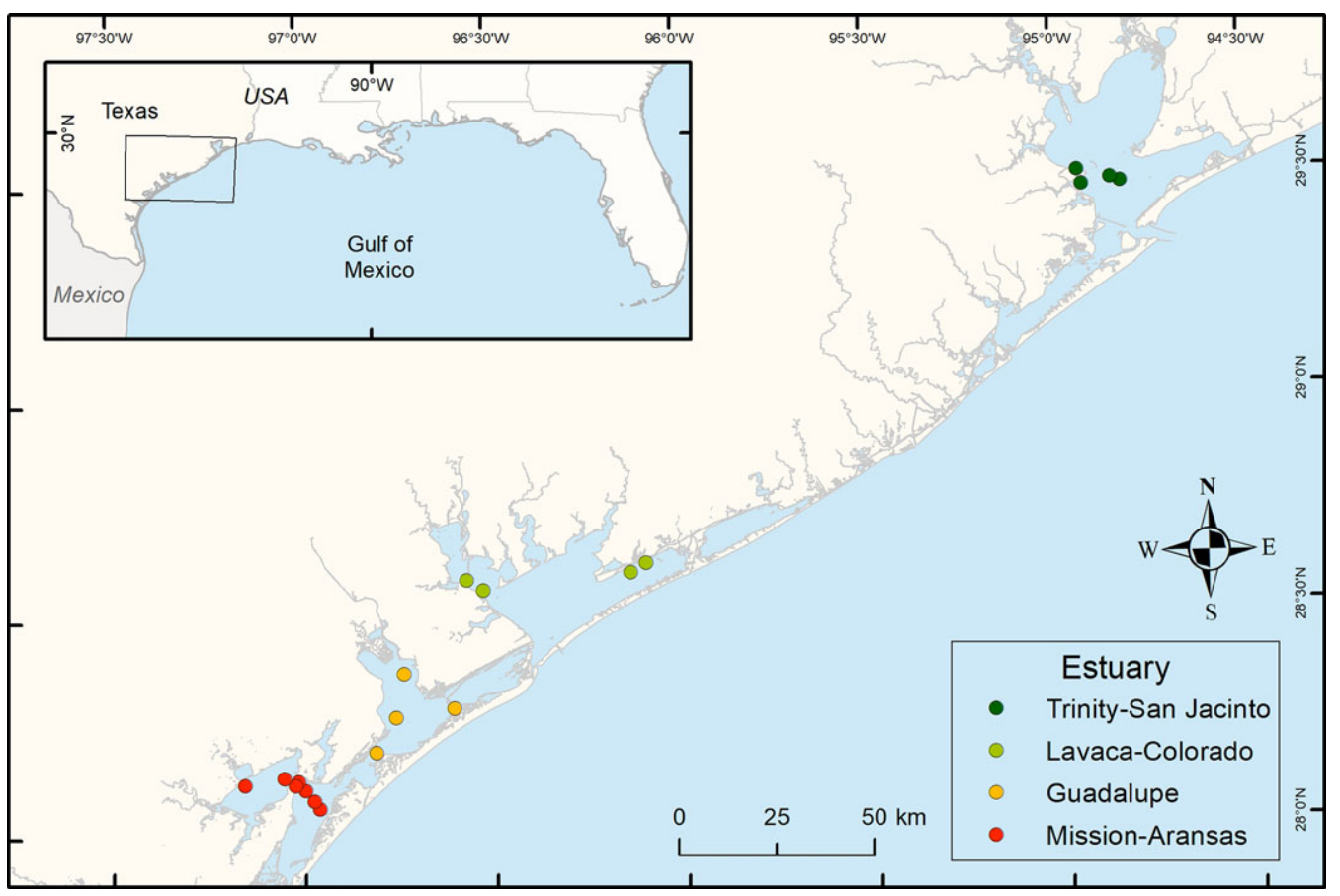

Figure 1. Sampling locations.

quantitative, areal oyster densities to facilitate accurate stock assessments. Oyster densities as collected by dredge were compared with concurrent diver-collected quadrat surveys to determine dredge efficiency for oyster collection because quadrat surveys can accurately quantify oyster densities.

\section{Methods}

Dredge efficiency comparisons were conducted at 19 locations within four Texas estuaries from July to October 2018 (Figure 1). The locations encompassed a range of environmental conditions and oyster densities within and among estuaries. Oysters were sampled in triplicate using quadrat samples taken by scuba divers $\left(0.5 \mathrm{~m}^{2}\right)$, and then dredge tows $\left(14.625 \mathrm{~m}^{2}: 0.375-\mathrm{m}\right.$ wide dredge for $30 \mathrm{~s}$ at $\left.1.3 \mathrm{~m} \mathrm{~s}^{-1}\right)$ at each location. Sediment grain size composition was approximated by visually observing and manipulating the substrate by hand to estimate the proportion of mud, sand, shell hash $(<25 \mathrm{~mm})$ and whole shell (live or dead) in the top $10 \mathrm{~cm}$ of each quadrat sample. After this grain size analysis, the abundance and volume of live and dead oyster shells $(>25 \mathrm{~mm})$ were standardized to unit area, and all live oyster heights were measured $(+/-1 \mathrm{~mm})$ in each sample. Shell volumes (dead and live) were determined by water displacement in a measuring bucket. Ancillary salinity and depth data were measured with a YSI ProDSS sonde at each location.

\section{Results}

There are positive linear relationships (Pearson correlations) between oyster metrics sampled by diver quadrat and dredge for live oyster density $\left(\mathrm{n} \mathrm{m}^{-2}, \mathrm{r}=0.78, \mathrm{p}<0.0001\right.$; Figure 2$)$, live oyster volume $\left(\mathrm{L} \mathrm{m}^{-2}, \mathrm{r}=0.67, \mathrm{p} \leq 0.002\right)$, and dead oyster density $(\mathrm{r}=0.51, \mathrm{p} \leq 0.03)$. The gear efficiency of the dredge as determined by linear regression on mean oyster densities $\left(\mathrm{n} \mathrm{m}^{-2}\right)$ collected by dredge and by quadrat at each station are 0.125 (SE 0.016) and 0.044 (SE 0.008) for live and dead oysters. Dredge efficiency (density $_{\text {dredge }} /$ density $_{\text {quadrat }}$ for each station) for live oyster density is negatively correlated (Pearson 


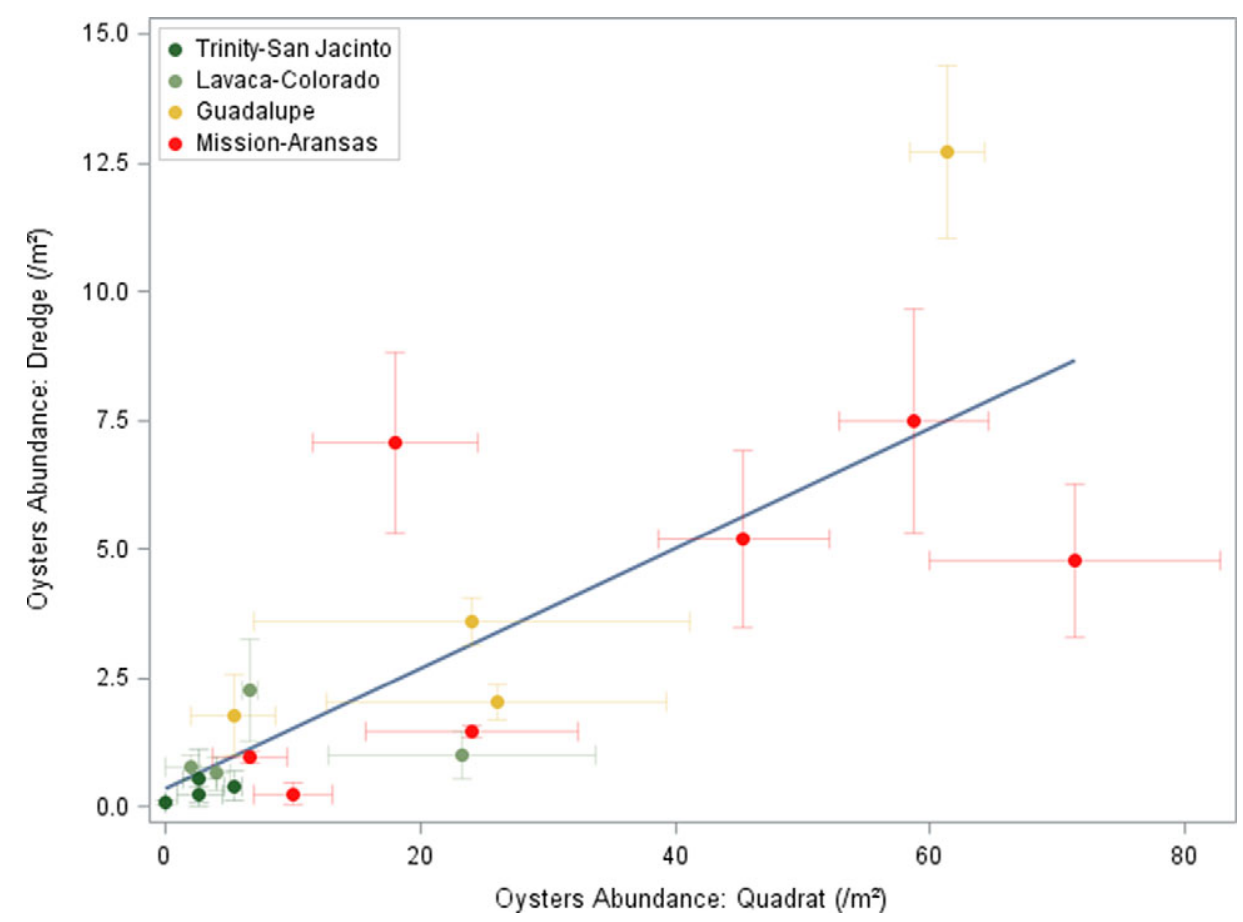

Figure 2. Oyster abundance as estimated by quadrat and dredge sampling. Error bars represent standard error of three replicates at each location.

correlation) with dead oyster density in quadrats and total oyster density and volume $(\mathrm{r}<-0.49, \mathrm{p}<$ $0.04)$, but no other oyster variables, sediment grain size components or water quality variables $(\mathrm{p} \geq 0.10)$. The sediment composition of the sampling locations are generally dominated by shell hash but vary among stations $(\mu=79 \%, \sigma=32 \%)$. The size distributions of live oysters are similar in quadrat and dredge samples where densities are high (Figure 3). Data generated in this study are available at GRIIDC (Beseres Pollack et al., 2019). Detailed results are in the Supplementary Material.

\section{Discussion}

Dredges provide a low-cost, rapid method for assessing oyster populations, but dredge-estimated oyster densities can be affected by several factors (e.g., tow speed, line length, dredge width, etc.), leading to dredges being labelled as unreliable tools for accurate oyster surveys (Schulte et al., 2018). However, dredge-estimated oyster densities were often less variable than quadrat-estimated densities in this study, which can be attributed to the fine-scale $(<10 \mathrm{~m})$ spatial homogeneity that is not detected by the larger area sampled by an oyster dredge. The lower efficiency of the dredge at higher shell densities is similar to that observed by Morson et al. (2018). But despite the perceived and observed sampling variability, there is still a strong linear correlation between dredge-based and quadrat-based oyster density estimates over a range of sediment types.

\section{Conclusions}

Despite its inefficiency, the oyster dredge is a useful sampling tool that can be used to estimate subtidal Crassostrea virginica densities after applying a correction factor. If the area sampled by oyster dredges used in monitoring studies can be estimated, then the efficiency ratio can be used as an estimate of actual oyster density for historical and future density assessments. Further sampling and statistical analyses, 


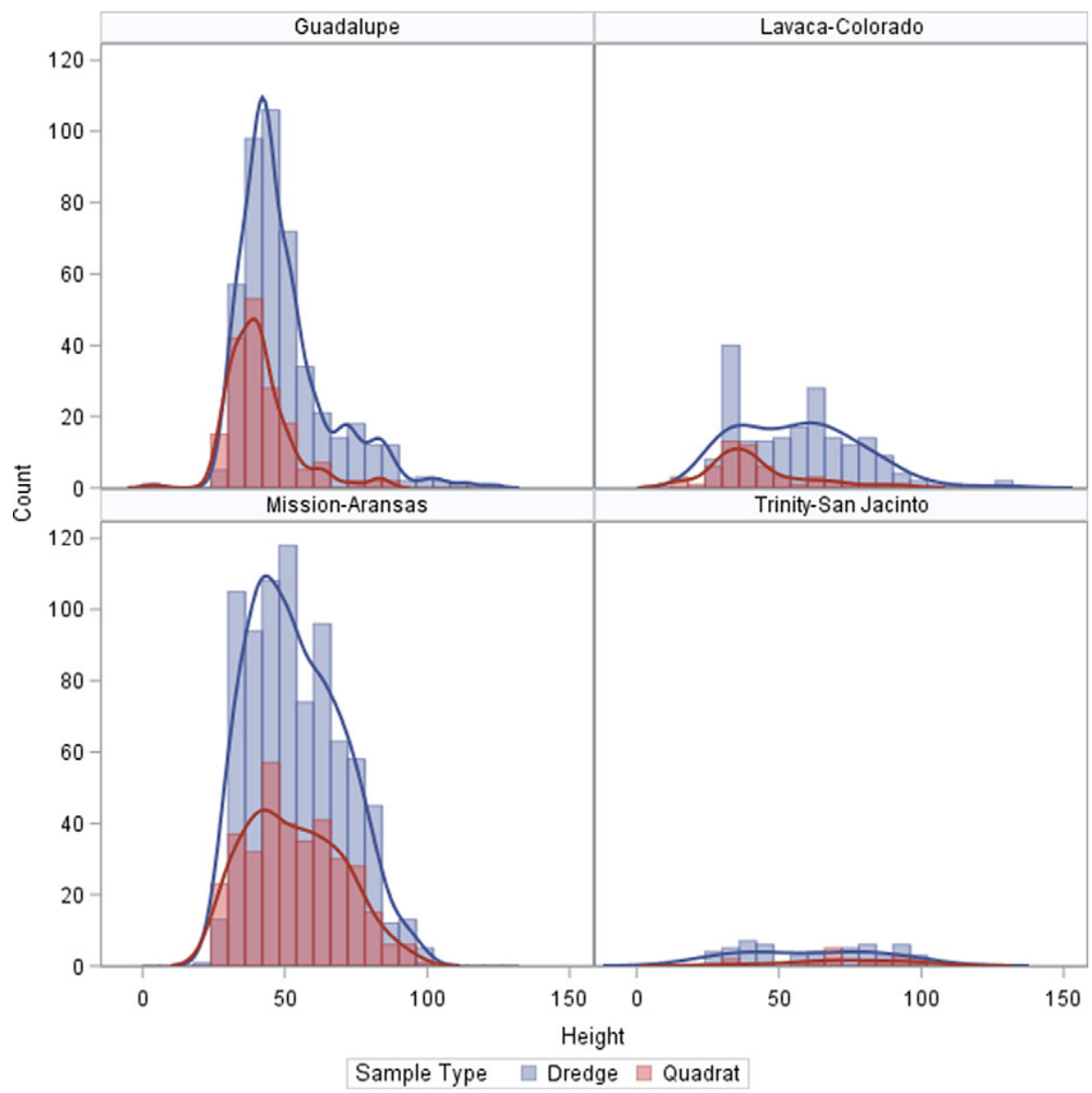

Figure 3. Histograms and kernel density curves of oyster heights in each estuary as sampled by dredge and diver quadrat.

such as those in Powell et al. (2007), could tease out more accurate gear efficiency ratios. However, the simple ratio developed in this study is useful and applicable to Gulf of Mexico estuaries for assessment and management of oyster populations.

Acknowledgements. The authors thank Natasha Breaux, Danielle Zimmermann, Meghan Martinez, Abe Margo, Abby Williams and Chris Groff for their assistance with field work and data entry. We also thank the Gulf of Mexico Research Initiative Information and Data Cooperative for storing, and allowing open access of, the data that was generated in this study (Beseres Pollack et al., 2019).

Author Contributions. JBP and TAP conceived and designed the study. TAP conducted data collection. TAP performed statistical analyses. JBP and TAP wrote the article.

Funding Information. This work was funded by the NOAA Texas Coastal Management Program, managed by the Texas General Land Office (GLO Contract \# 18-093-000-A604).

Conflict of Interest. JBP and TAP declare none.

Supplementary Materials. To view supplementary material for this article, please visit http://dx.doi.org/10.1017/exp.2019.2. 


\section{References}

Beseres Pollack, J., Palmer, T., \& Breaux, N. (2019). Comparison of oyster populations sampled by dredge and quadrat. Distributed by: Gulf of Mexico Research Initiative Information and Data Cooperative (GRIIDC), Harte Research Institute, Texas A\&M University-Corpus Christi. doi:10.7266/DRCEDRM3

Chai, A.-L., Homer, M., Tsai, C.-F., \& Goulletquer, P. (1992). Evaluation of oyster sampling efficiency of patent tongs and an oyster dredge. North Am J Fish Manage, 12, 825-832. doi: 10.1577/1548-8675(1992)012<0825:EOOSEO>2.3.CO;2

Martinez-Andrade, F. (2018). Trends in Relative Abundance and Size of Selected Finfishes and Shellfishes along the Texas Coast: November 1975-December 2016. Texas Parks and Wildlife Department, Management Data Series, no. 293. doi: 10.13140/RG.2.2.14487.06565.

McLoughlin, R.J., Young, P.C., Martin, R.B. \& Parslow, J. (1991). The Australian scallop dredge: estimates of catching efficiency and associated indirect fishing mortality. Fish Res, 11, 1-24. doi: 10.1016/0165-7836(91)90030-J

Meyer, T. L., Cooper, R.A., \& Pecci, K.J. (1981). The performance and environmental effects of a hydraulic clam dredge. VS Nati Marine Fish Service Marine Fish Rev, 43(9), 14-22.

Morson, J.M., Munroe, D. Ashton-Alcox, K., Powell, E.N., Bushek, D. \& Gius, J.E. (2018). Density-dependent capture efficiency of a survey dredge and its influence on the stock assessment of eastern oysters (Crassostrea virginica) in Delaware Bay. Fish Res, 205, 115-121. doi: 10.1016/j.fishres.2018.04.012.

Powell, E.N., Ashton-Alcox, K.A., Dobarro, J.A., Cummings, M., \& Banta, S.E. (2002). The inherent efficiency of oyster dredges in survey mode. J Shellfish Res, 21, 691-695. doi: 10.1577/M04-205.1

Powell, E.N., Ashton-Alcox, K.A., \& Kraeuter, J.N. (2007). Reevaluation of eastern oyster dredge efficiency in survey mode: Application in stock assessment. North Am J Fish Manage, 27, 492-511. doi:10.1577/M04-205.1

Schulte, D. M., Lipcius, R. N., \& Burke, R. P. (2018). Gear and survey efficiency of patent tongs for oyster populations on restoration reefs. PLoS ONE, 13(5), e0196725. doi: 10.1371/journal.pone.0196725

Cite this article: Beseres Pollack J, Palmer TA (2020). Crassostrea virginica dredge efficiency in Texas estuaries Experimental Results, 1, e2, 1-8. https://doi.org/10.1017/exp.2019.2 


\section{Peer Reviews}

\section{Reviewing editor: Dr. Arne Linlokken}

Inland Norway University of Applied Sciences, Faculty of Applied Ecology, Agricultural Sciences and Biotechnology, Elverum, Norway, 2418

This article has been accepted because it is deemed to be scientifically sound, has the correct controls, has appropriate methodology and is statistically valid, and met required revisions.

doi:10.1017/exp.2019.2.pr1

\section{Review 1: Crassostrea virginica dredge efficiency in Texas estuaries}

Reviewer: Megan LaPeyre

Louisiana State University, School of Renewable Natural Resources

Date of review: 08 November 2019

Published online:

Conflict of interest statement. Reviewer declares none.

Comments to the Author: This paper provides a much needed means to translate oyster dredge sampling data to a useable and comparable density. The data and analyses are sound. A few minor questions: (1) what is "dead oyster" versus "shell volume" or "whole shell"? (2) how was the proportion of mud, sand, shell hash and whole shell estimated BEFORE the top $10 \mathrm{~cm}$ was excavated? Is there visibility to do this? And how were these data used? If not used, no need to report- although it would be interesting to know what rough estimate of "percent cover" or hard bottom there was. (3) It might be worth noting that use of the dredge and conversion factor could be an issue in areas with high amounts of material (live or dead oyster, shell, hash), which result in the dredge being full prior to finishing the sample. L. 78 - where you state "several factors" please identify some of the factors that can affect dredge estimates (i.e., two speed, line length, weather conditions, dredge width, overflow on dredge... )

\section{Score Card}

Presentation

5.0

Is the article written in clear and proper English? (30\%)

Is the data presented in the most useful manner? (40\%)

Does the paper cite relevant and related articles appropriately? (30\%)

\section{Context}

Does the title suitably represent the article? (25\%)

Does the abstract correctly embody the content of the article? (25\%)

Does the introduction give appropriate context? (25\%)

Is the objective of the experiment clearly defined? (25\%) 
Are the limitations of the experiment as well as the contributions of the experiment clearly outlined? (20\%) 


\section{Review 2: Crassostrea virginica dredge efficiency in Texas estuar}

Reviewer: David Bushek

Rutgers University, Haskin Shellfish Research Laboratory

Date of review: 11 November 2019

Published online:

Conflict of interest statement. Lead author is co-PI on a project I have funded to build a database on oyster diseases through the Gulf, but this is unrelated and should not present a COI

Comments to the Author: Nice paper. A few comments.

Suggest authors read and discuss: Morson, J. M., D. Munroe, K. Ashton-Alcox, E. N. Powell, D. Bushek, \& J. E. Gius. (2018). Fisheries Research, 205, 115-121. DOI: 10.1016/j.fishres.2018.04.012.

Describe how mud, sand and shell were estimated in quadrat - L58-60

L60-71: is this a multiple regression? Can these relationships be shown and some discussion of what their importance may be useful.

\section{Score Card}

Presentation

Is the data presented in the most useful manner? (40\%)

Does the paper cite relevant and related articles appropriately? (30\%)

\section{Context}

Does the title suitably represent the article? (25\%)

Does the abstract correctly embody the content of the article? (25\%)

Does the introduction give appropriate context? (25\%)

Is the objective of the experiment clearly defined? (25\%)

Are the limitations of the experiment as well as the contributions of the experiment clearly outlined? (20\%) 